\title{
The contribution of modified taungya system to forest cover and livelihoods of forest-fringe communities: A case study of Worobong South Forest Reserve in Ghana
}

\author{
ASARE-KISSIEDU EBENEZER ${ }^{1}$, G. K. AMEKA ${ }^{2, \bullet}$ TED Y. ANNANG ${ }^{3}$ \\ ${ }^{1}$ Department of Plant and Environmental Biology, University of Ghana. Legon, Accra, Ghana \\ ${ }^{2}$ Department of Botany, University of Ghana. P.O. Box LG55 Legon, Accra, Ghana. ^email: kgameka@ug.edu.gh \\ ${ }^{3}$ Institute of Environment and Sanitation Studies, University of Ghana. Legon, Accra, Ghana \\ Manuscript received: 7 January 2018. Revision accepted: 14 May 2018.
}

\begin{abstract}
Ebenezer A, Ameka GK, Annang TY. 2018. The contribution of modified taunga system to forest cover and livelihoods of forest-fringe communities: a case study of Worobong South Forest Reserve in Ghana. Asian J Ethnobiol 1: 15-30. The purpose of this study was to consider the function of the MTS in assisting forest recovery and in ameliorating the subsistence of peasants within the Worobong South Forest Reserve (WSFR, Akim portion). Geographic Information System (GIS) and Remote Sensing (RS) were utilized to examine the expanse of forest canopy decrease from 1990-2010. The analysis of the involvement of the MTS strategy on forest canopy recovery was also performed by analogizing the natural forest to the MTS plantation by utilizing the $100 \mathrm{~m} \mathrm{x} 100 \mathrm{~m}$ square transect techniques and using the Simpson's Index of Diversity. A socio-economic survey including semi-structured interviews was performed to find out the thinking of the MTS peasants in the Akwansrem, Feyiase, and Miaso communities and forestry officials on forest recovery and the contribution of the MTS to livelihoods of peasants in the study area. The study results showed that the forest canopy in the WSFR had experienced various alterations and/or enhancements, particularly in the closed forest canopy. The jungle canopy declined by $0.41 \%$ and $0.17 \%$ in $1990-2000$ and $2000-2010$, respectively. Nevertheless, a principal alteration was examined within the closed canopy in terms of forest vegetation categories. Between 1990-2000, the closed canopy underwent a decline of $45.55 \%$, but it had an increase of 1.25\% (41.4 ha) in 2000-2010. It was expected that there would be a further enhancement in the closed canopy in 2010-2020 if the current recovery rate continues to grow. The Simpson's Index of Diversity showed that the natural forest transect was more diverse $(1-\mathrm{D}=0.93)$ in terms of variety and distribution than the MTS transect $(1-\mathrm{D}=0.41)$. And, stem number was nearly 50\% higher than that of the MTS plantation. The research results showed that around 600 to 800 trees were planted by individual peasants annually on 0.8 ha of downgraded lands. The enhancement of closed forest canopy within WSFR was ascribed to the success of the MTS strategy. The results also signified that the subsistence of MTS peasants (concerning their access to livelihoods and farm products and their ability to bear the expense of their children's education and to construct buildings) had raised. Still, fear of future expectations and continuity of the MTS, unbalanced distribution of MTS farms, wildfires, and illegal logging were several affairs considered impending to the strategy. As a result, several suggestions have emerged. Some of these were: routine evaluation of the contexture and spatial degree of the forest cover to keep track of alterations with the application of GIS and RS; The requirement to explain the directives and advantages of the MTS strategy to farming societies and; the implementation of laws to fulfill the policies that will guarantee continuous management of the forest.
\end{abstract}

Keywords: Forest cover, Ghana, livelihoods, taungya system

\section{INTRODUCTION}

Forests are avowed to have several roles at international, regional, and local stages. They serve as a source of wood and non-wood products with economic value such as industrial wood, wood fuel, fiber, food, medicines, soil generation, soil and water conservation. Other services set up by woods are refining air and water, nutrient recycling, keeping biological diversity (habitats, species, and genetic resources), alleviation of climate alteration and carbon isolation, and protection for the vast majority of terrestrial biodiversity. The jungle accommodates occupation, livelihood, enjoyment, conservation, and natural and cultural heritage (World Bank 2005). Furthermore, the Food and Agriculture Organization (FAO 2001) approximates that 60 million local people live within forests and depend on them entirely. With some extent of dependency, much larger numbers live on the fringes of forests; thus, people's reliance on trees and jungle is infinite. The World Bank also informed that around 1.6 billion people in the world depend on forest founts for their living (World Bank 2001), and 86\% of rural people (2.6 billion) are taking part in agriculture (including forestry) to bring about food and cash (Crowley 2010).

Nevertheless, the denudation rate is rising globally caused by the alteration of forests by farming labors involving commercial farms and swidden agriculture, logging, fuelwood collection, grazing, and increasing urbanization and industrialization. About $80 \%$ of the world's forest regions declined intensely over the past three decades leading to the decrease of the earth's capability to absorb carbon dioxide (UNEP 2000). According to the United Nations Food and Agricultural Organization, about $30 \%$ of the forest region vanished in 1990 and 2005 alone 
(FAO 2006). This situation has contributed to the deliverance of high levels of greenhouse gases into the atmosphere because trees are cut down (World Bank 2010).

Forest founts in Ghana's forest regions have vanished at a worrying number. Ghana lost roughly $80 \%$ ( $8 \mathrm{~m}$ ha -1.6 $\mathrm{m}$ ha) of its forest canopy in 1900 and 1990, influencing the biodiversity and essential sources of subsistence for the bucolic populations (Ghana Forestry Commission 2002; Opoku 2006). The Ghana Forestry Commission (2002) further informed that some forest conservations such as Pamu Berekum in the Brong Ahafo Region had lost over $98 \%$ of its forested cover within the same period.

According to Opoku (2006), the role of forest-fringe societies in the vast devastation of the forest has brought to visualizing the forest as an "economic, social and human rights"e decomposition." Therefore, reforestation and plantation arrangements are becoming more and more significant to replenish the disafforested and downgraded natural forests. The Forest and Wildlife Policy, set up in Ghana in 1994, underlines the significance of collaborative forestry management (CFM) and community-based natural resource management (CBNRM). These have acted as a catalyst in familiarizing numerous arrangements to rectify people's entryway to forest and tree founts. Additionally, attempts have been built to preserve the remaining forests by establishing forest sanctuaries, resulting in two management arrangements for Ghana's forests: forest reserves and off reserves (IUCN 1996).

Reforestation and plantation arrangements in the downgraded areas of the forest reserves comprise the Modified Taungya System (MTS), while private timber tree plantations are remarkable in the off-reserve regions. All these arrangements are under the National Forest Plantation Development Programme (NFPDP) umbrella, launched in 2001. The 1994 forest and wildlife policy aim at "conservation and sustainable development of the nation $^{\text {ee }}$ forest and wildlife founts for the conservation of environmental quality and the perpetual flow of optimum benefits to all segments of society" (MLF 1996). This was followed by the re-launch of the NFPDP in 2001. To stimulate the participation of peasants in the program to restore lost forest (FPDC 2002), enhance food security, and ultimately reduce poverty become the aims of the NFPDP (Ghana Forestry Commission 2004). The Traditional Taungya System (TTS) is modified to be MTS adopted for implementing the NFPDP.

Producing commercial timber and food crops and interplanting crops and trees become the aim of the TTS. 35,000 ha of forest plantations were developed in 2000 through the TTS (Agyeman et al., 2003). Yet, records at the Forest Service Division (FSD) showed the confirmation of mixed successes. The problems of species-site-matching, inadequate expertise, and supervision were the significant challenges faced by the TTS arrangement. The farming in unauthorized forestlands and the devastation of tree seedlings were abuses of the TTS arrangement. In 1984, the TTS was adjourned (IUCN 1996). Despite the challenges and abuses, forest communities requested its reintroduction with changes because Taungya is viewed as a beneficial forest tenure system for restoring forest cover and improving peasants' wellbeing (FAO 2003). Therefore, the TTS was modified under the 1994 Forest and Wildlife Policy ratified by the Ministry of Lands and Forestry (MLF) and became the MTS (MLF,1996). To help achieve the NFPDP goals becomes the expectation of this. The NFPDP aims to encourage the development of a sustainable forest fount base that will satisfy future demand for industrial timber and enhance environmental quality. Also, the program is intended to create jobs and significantly raise food production in the country, thereby increasing wealth creation and lowering rural poverty (NFPDP 2008).

The study's objectives were: (i) To study the spatiotemporal alterations in forest cover and the contribution of the MTS scheme in forest cover recovery reestablishment within the WSFR over the last two decades (1990-2010). (ii) To discover the benefits of the MTS scheme to local peasants.

\section{MATERIALS AND METHODS}

\section{Study area \\ Location, extent, and ownership}

Worobong South Forest Reserve (WSFR, Akim Portion) is located in latitudes $6^{\circ} 30^{\prime} \mathrm{N}$ and $6^{\circ} 24^{\prime} \mathrm{N}$ and longitudes $0^{\circ} 33^{\prime} \mathrm{W}$ and $0^{\circ} 21^{\prime} \mathrm{W}$. The Forest Reserve lies in the Eastern Region of Ghana within the Fanteakwa District Assembly with the headquarters at Begoro. The Forest Reserve forms part of the Forest Management Unit (FMU) 44. WSFR (Akim Portion) shares common boundaries with Southern Scarp Forest Reserve (Akim Portion) in the southwest and the WSFR (Kwahu portion) in the northeast. The WSFR (Akim Portion) covers an entire region of $10,935.00$ ha (109.35) with a total perimeter of $71.72 \mathrm{~km}$. The external boundaries are fixed with concrete pillars at approximately $800 \mathrm{~m}$ intervals. There are fifteen admitted farms in reserve covering a region of 233.14 ha $(575.85$ acres), with an internal perimeter of $30.69 \mathrm{~km}$. The internal farm boundaries are marked by cut lines with wooden beacons at the corners except for the first corners where concrete pillars bearing the number of the farm have been erected. The Akwansrem village is wholly within the Reserve with an admitted village-land region of 91.31 ha (225.53 acres). The land cover map of WSFR (Akim Portion) is presented in Figure 1 (Forest Management Plan 2013).

Ownership of WSFR (Akim Portion) is vested in the Begoro stool, which owes its allegiance to the Omanhene of Akim Abuakwa. The Reserve was then publicized by the Forestry Department in 1928 and gazetted by Gold Coast Governor Order Number 17 of 1936 (Forest Order Sec 15 of Cap 63 of 1936) (Forest Management Plan 2013).

\section{Physical environment}

According to the Forest Management Plan (2013), the WSFR falls within the Moist Semi-Deciduous South East (MSSE) Sub Type vegetation region and the Tropical humid Climatic region. The average annual rainfall ranges between 1,250 $\mathrm{mm}$ and 1,500 $\mathrm{mm}$. The mean maximum 
temperature ranges between $27^{\circ} \mathrm{C}$ and $35^{\circ} \mathrm{C}$ while the minimum lies between $19^{\circ} \mathrm{C}$ and $23^{\circ} \mathrm{C}$. The three-storied structure is in certain parts, though most forest conservation is two-storied, and the emergent trees are relatively close together. Hilly and rocky at most parts with $50 \%$ of the slope greater than $15^{\circ}$ are the contours of the conservation area, but the rest of the region is relatively flat. The hilly regions have some steep slopes with contours varying between $1,840 \mathrm{~m}$ and $2,330 \mathrm{~m}$ above sea level, and these are laid in the central and southwestern part of the Conservation. The west end of the Forest Conservation overlies the upper and lower Birimian series rocks. The Voltaian Sandstones cover most parts of the remaining region. The soil color is reddish to brown, and the ground is mostly sandy loam with patches of clay. The Conservation is dissected by perennial streams such as Mia (at the western portion), Sutwum and Nubeso (at the southern portion), and the Worobong (at the northern part). The forest-fringe communities are Feyiase, Mianya, Ayigbetown, Miaso, Pillar 10, Asarekwao, Akwamu, Kotoku, Kumfere, Ankensu, Owusukrom, Esaase, Ahomahomasu, Kronkronso, Bisibuom, Pesiator, Akoradarko, Amokrom, Apaa, Opare, and Begoro. Akwansrem community is the only community situated in the conservation (Forest Management Plan 2013).

\section{Stands diagnostic of the conservation}

The total volume of timber in the WSFR is estimated at $3,359,888 \mathrm{~m}^{3}$, of which $1,158,235 \mathrm{~m}^{3}(34.5 \%)$ is greater than $70 \mathrm{~cm} \mathrm{dbh}$ and $2,201,653 \mathrm{~m}^{3}(65.5 \%)$ is between 10 $69.9 \mathrm{~cm} \mathrm{dbh}$. The total volume of economic timber species is estimated at $2,061,466 \mathrm{~m}^{3}$, of which $870,863 \mathrm{~m}^{3}$ are greater than $70 \mathrm{~cm}$ dbh. Timber species average 188.5 (approximately 42.2\%) consists of trees greater than $70 \mathrm{~cm}$ $\mathrm{dbh}$, and 37.1 (approximately 19.7\%) consists of trees greater than $110 \mathrm{~cm} \mathrm{dbh}$. The mean basal region for the Conservation is $\mathrm{m}^{2} / \mathrm{ha}$. Timber species account for 99 (58.9\%) stems per ha, while all other species apart from timber constitute $69(41.1 \%)$ stems per ha (Forest Management Plan 2013).

\section{Stocking of species}

A total of 210 species have been recorded in the Conservation, of which 59 are timber species (Forest Management Plan 2013). Timber species such as Chrysophyllum subnudum, Triplochiton scleroxylon, Cylicodiscus gabunensis, Entandrophragma candollei, Piptadeniastrum africanus, and Turraenthus africanus are well represented above $70 \mathrm{~cm}$ dbh (more than 40 stems per $100 \mathrm{ha}$ ) in the Conservation. Others such as Albizia zygia, Celtis milbraedii, Celtis adolfi-friderici, Nesogordonia papaveriferii, Piptadeniastrum africanum, Chrysophyllum subnudum, Hannoa klaineana, Parkia, Sterculia rhinopetala, Guregion cedrata, Parkia bicolor, Petersianthus macrocarpus, Piptadeniastrum africanus, Turraenthus africanus, and Strombosia glaucescens also have a satisfactory level of stocking. However, timber species such as Anopyxis klaineana, Ceiba pentandra, Daniellia ogea, Dailium aubrevellei, Entandrophragma candollei, Holoptelea grandis, Morus mesozygia, Okoubaka aubrevillei, and Terminalia Superba appear to have low stem distribution in the Conservation (Forest Management Plan 2013).

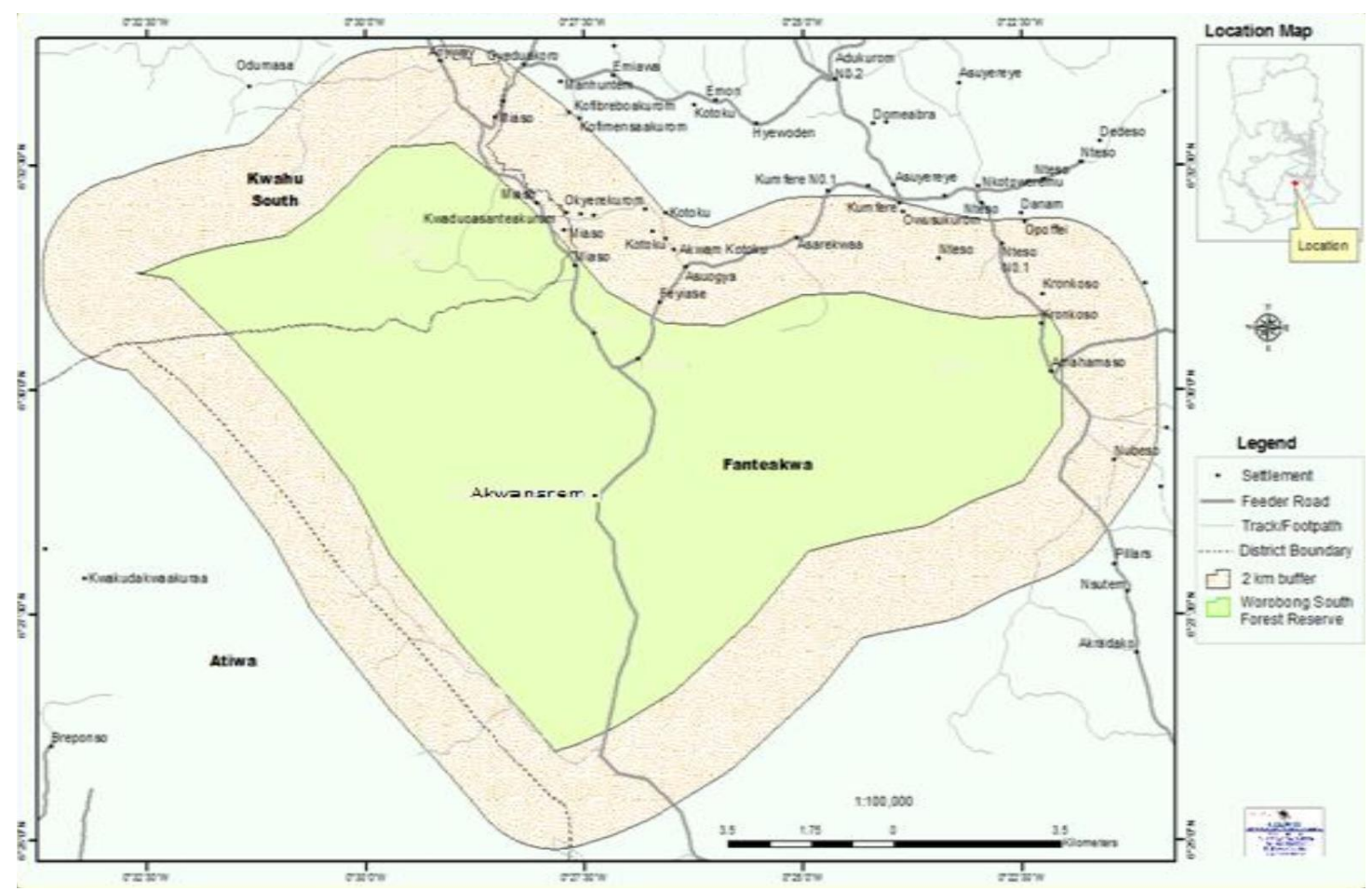

Figure 1. Map of Worobong South Forest Reserve (Akim Portion) with a 2 km buffer (CERSGIS 2013) 


\section{Socio-economic activities}

The economy of the fringe-forest societies around the Forest Conservation is mainly agriculturally based. The populations are primarily peasants who mainly cultivate plantain, maize, cocoyam, yam, cocoa, oil palm, and vegetables like cabbage, tomato, garden eggs, okra, and pepper. The main non-agricultural activity is petty trading, and basket weaving is the cottage industry in the region. Wednesdays are observed as "taboo days" for visiting the conservation. There is an exclusion region in the Forest Conservation which serves as a sacred grove believed to be the abode of the wife of the fetish, Bosompra (Forest Management Plan 2013).

\section{Methods}

\section{Desk study of literature}

To understand legal access rights to forest founts, regulations on benefits in conservations and off conservations in Ghana, and the Benefit-sharing Agreement of MTS, a desk-study of relevant literature was performed. This information was gathered from a review of pertinent forest policies and acted, and the 2013 Worobong Forest Conservation Management Plan.

\section{Forest cover change analysis}

To ascertain temporal and spatial alterations in forest cover, at least two time-periods data sets are needed (Jenson 1986). This study utilized three-time interval data sets for 1990, 2000, and 2010 calendar years. The analysis was performed using optical satellite imagery to create a time series of images. A set of high-resolution multisensorial and multi-temporal satellites images from the Landsat (TM and ETM+) family of satellites were examined. Cloud-free scenes were acquired for 1990 (Landsat TM), 2000 (ETM+), and 2010 (Landsat ETM+) during the dry season. The Landsat TM and ETM+ images were geo-referenced using 1:50,000 topographic data sets from the Ghana Survey Department. The images were acquired from the Centre for Remote Sensing and Geographic Information Services (CERSGIS 2013) at the University of Ghana (Table 1).

\section{Satellite imagery, processing, and classification}

A particular method in establishing forest cover maps with satellite imagery requires explaining spectral classes by clustering the image data and assigning pixels into classes (CERSGIS 2013). The Interactive Self-Organizing Data Analysis Technique Approach (ISODATA) algorithm performed unsupervised classification with maximum iteration set at 99, convergence threshold at 0.9 , and several classes set at 30 . The threshold value of 0.9 and maximum iteration values of 99 were utilized to ascertain the exactness of the categories. Noise in the images was eliminated by passing a $3 \times 3$ majority filter over the resulting vegetation cover and land-use images. Ground truthing of the images was performed in the study region to ascertain the positional exactness of the images using a Global Position System. In relatively flat regions, correction for terrain displacement is not necessary (Boakye et al. 2008), but in the mountainous areas such as the WSFR, orthorectification was utilized to avoid overlapping images. The image processing software ERDAS IMAGINE 8.4 was used for the analysis.

A post-classification method was utilized to classify the images into forest cover/land-use types (Mas 1999). The most apparent method used in alteration detection studies is the post-classification method based on a comparative analysis of images acquired at different moments after independent classification. This method has the advantage of minimizing the problem of normalization for atmospheric and sensor differences between different dates (Singh 1989) since the images were from different sensors, taken on different dates by CERSGIS, and had been independently classified and labeled, the post-classification method to change detection was considered suitable for this study.

The classification image referencing was carried out to maintain the original Digital Number (DN) grayscale value during classification. All categories generated during the unsupervised classification process were converted into a binary image because the primary purpose was to detect temporal and spatial alteration in vegetation cover. Since 1960, the rasterized image of the WSFR of Ghana has not been regenerated. Thus, this image marked the forest boundary to remove misclassified pixels outside the forest boundaries. The alterations in recorded forest cover included the alteration from forest to non-forest for logging, bushfires, and tree crop plantation using ArcView 3.3 GIS software.

Specifically, the following processes were carried out:

Acquisition of raw satellite image. This is the first step in this procedure (Figure 2. A).

Rectification or geo-referencing the raw image to Ghana Projection System. That is assigning Ghana Coordinates to the image using 1:50000 Ghana Topographic data. Example: Roads and Settlements from Survey Department. Rectification means the method of protruding the data onto a plane and creating it cohere to a map projection system. To assign map coordinates to the data is geo-referencing. As all map projection systems are related to map coordinates, rectification involves georeferencing (Figure 2. B).

Classification of images. Classification means the method of classifying pixels into a finite number of individual categories, or classes, of information based on their record values. If a pixel meets a particular set of criteria, the pixel is allotted to the category corresponding to the standards. There are two ways to classify pixels into different categories, namely:

Table 1. Characteristic of remote sensing imagery data

\begin{tabular}{lllcc}
\hline Image type Sensor & Bands & $\begin{array}{c}\text { Date of } \\
\text { acquisition }\end{array}$ & $\begin{array}{c}\text { Spatial } \\
\text { resolution }\end{array}$ \\
\hline Landsat & TM & $453($ RGB) & $08 / 02 / 1990$ & $30 \mathrm{~m}$ \\
Landsat & ETM+ & 453 (RGB) & $14 / 02 / 2000$ & $30 \mathrm{~m}$ \\
Landsat & ETM+ & 453 (RGB) & $01 / 02 / 2010$ & $30 \mathrm{~m}$ \\
\hline
\end{tabular}


They are supervised and unsupervised. Supervised classification is more closely controlled by the user than unsupervised classification. During this method, we decide on pixels that represent patterns recognized or will ascertain with facilitating from different sources. Information on the data, the desired categories, and the formula to be utilized are needed before start choosing training samples. By determining patterns within the imagery, it'll be able to "train" the computer systems to spot pixels with similar characteristics. By setting priorities to those categories, it supervises the classification of pixels as they are appointed to a category value. At the same time, unsupervised classification is more computer-automated. It permits the specification of the computer's parameters as guidelines to expose statistical patterns within the knowledge. Initially, the Unsupervised Classification choice was chosen, and so the classified pictures were verified using Global Positioning System (GPS) for the aim of orientation within the field.

Recoding. The next step is recoding, namely, to assign a new category value number to all categories, making a new thematic raster layer utilizing the new category numbers. Some of the classes were combined through this method. After recording, the raster attribute table was exported as .dat. The exported file was processed in excel, and statistics for all the varied categories were generated Once the scale of a pixel was found out (e.g., the Landsat $30 \mathrm{~m} \times 30 \mathrm{~m}=900 \mathrm{~m})$, then the pixels per category were multiplied by 900 to gain the entire region in meters per category, and this was divided by 10,000 to acquire hectares, then finally was divided by 100 to achieve sq. kilometer (Figure 2. C).

Map composition. Several maps were finally drawn up exhibiting the alterations in the cover types, with statistics showing the alterations from 1990, 2000, and 2010.

Exactness assessment. Randomly chosen points per category were made at the Centre for Remote Sensing and Geographic Information Services (CERSGIS) office. Category sampling to verify exactness was as follows: closed forest fluvial vegetation (15), Open-forest fluvial vegetation (20), Dense shrub/herbaceous (20), etc. Within the closed forest, 13 was impenetrable forest fluvial while 2 was Open fluvial vegetation, and hence to calculate the exactness of the impenetrable forest fluvial vegetation, the formula was $13 / 15 \times 100$. This formula was applied to all the categories to acquire the matrix in Table 5.

\section{Analysis of forest diversity of the natural forest and the Modified Taungya System (MTS) plantation}

It is impossible to calculate each living and non-living thing in an ecosystem. Therefore, an excellent technique for locating what things exist in an ecosystem is by developing transects (NMSU 2013). A transect is an ecological tool helping to calculate the relative abundance of organisms in a region. Additionally, the NMSU (2013) depicts transect as an accounted region where sample population counts of plants and animals may be acquired. The accounted region needs to be wide enough to characterize the ecosystem's biotic and abiotic factors. To trace alterations from time to time, it is significant for the researchers to measure alterations in abundance (Philippoff and Cox 2013). Further, a line transect with a certain interval is used, which is simple to utilize in the field. Transect lines might be created from measuring tape or rope with a mark at periodic intervals. The dimension of the transect (whether a one-meter sq. or a 10-meter or perhaps a 100-meter square) is decided by the biotic factors within the region to be examined (NMSU 2013).

So, this study applied the $100 \mathrm{~m} \times 100 \mathrm{~m}$ sq. transect method to form a comparative analysis of the natural forest and, therefore, the MTS plantation inside the WSFR. A preliminary survey was performed to pick the transect sites and applicable methods (Figure 3 ).

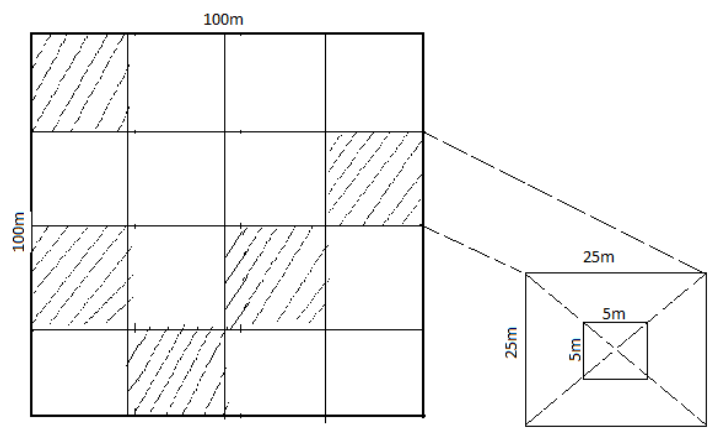

Figure 3. $100 \mathrm{~m}$ x100 m square transect

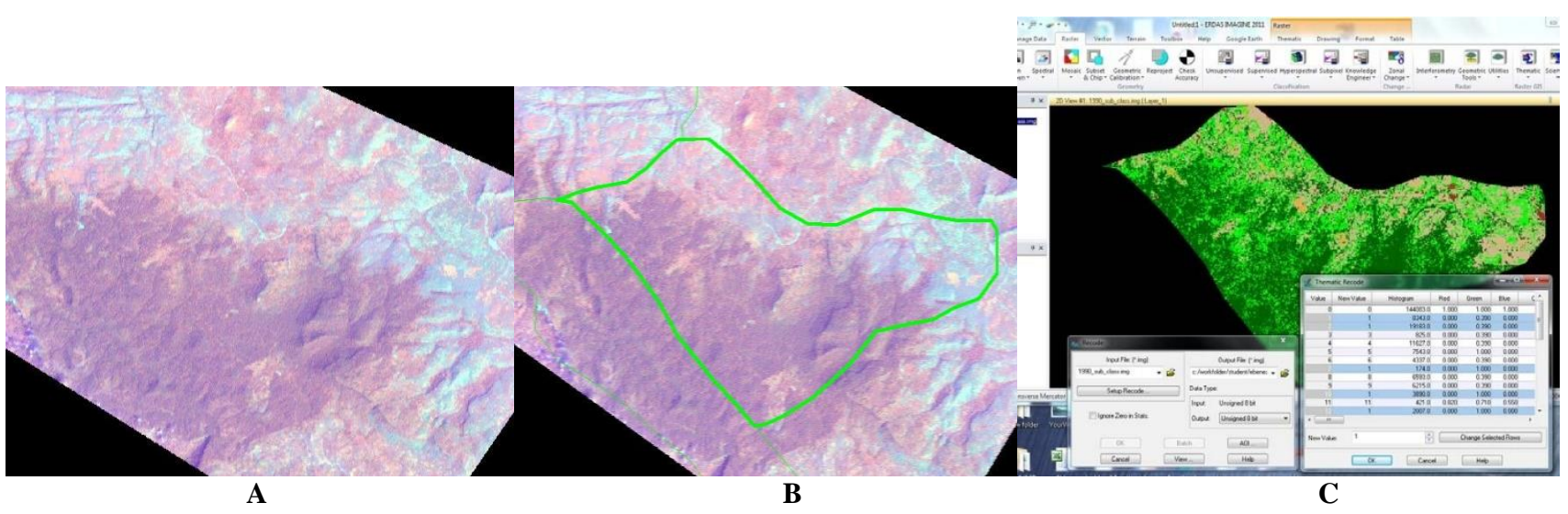

Figure 2. A. Acquisition of raw satellite image; B. Rectification or Geo-referencing the primary image to Ghana Projection System; C. Recoding 
The $100 \mathrm{~m}$ x100 m square was calculated for both sites. Each site was split into 16 plots of $25 \mathrm{~m} \mathrm{x} 25 \mathrm{~m}$ square. The calculations were performed with a measuring tape, tagged with a cutlass, and fixed with pegs. 5 plots were sampled separately and randomly for both sites. All trees $\geq 10 \mathrm{~cm}$ diameter at breast height ( $\mathrm{dbh}$ ) were calculated and recorded, registering unusual species. Then, within each sample $(25 \mathrm{~m} \times 25 \mathrm{~m})$, a quadrant of $5 \mathrm{~m} \times 5 \mathrm{~m}$ was measured with a tape measure and fixed with pegs and all tress species $\geq 1 \mathrm{~cm}$ dbh was also calculated and recorded. The circumference of the tress was measured with a tape measure, and the dbh of tress was calculated by dividing the circumference of individual trees by $=3.14$. Further, identifying all tree species was performed in the field. In contrast, those that could not be identified immediately were taken to the Herbarium at the Department of Botany, University of Ghana, for identification.

This method supplies the researcher with the tools required to answer his own ecological questions and develop comparisons among sites (Philippoff and Cox 2013). This experience led the researcher to a proper understanding of what made the WSFR what it was.

\section{Simpson's Index of Diversity}

The nature of this research needed that the stem numbers of trees in each transect should be counted. This was performed by calculating the number of trees. Meanwhile, species diversity (species richness, evenness, and relative abundance) was examined with Simpson's diversity index. In line with Powell (1982) and Brower and Zar (1984), Simpson's Diversity Index measures diversity. In ecology, it is often utilized to calculate the biodiversity of a habitat. It calculates the number of species present and the abundance of each species. Simpson's Index (D) measures the chance that two individuals randomly picked out from a sample may belong to the same species (or the same category other than species).

The formula for calculating $\mathrm{D}$ is

$$
\mathrm{D}=\frac{\sum n(n-1)}{\mathrm{N}(\mathrm{N}-1)}
$$

Where :

$\mathbf{n}=$ the total number of organisms of a particular species

$\mathbf{N}=$ the total number of organisms of all species

The grade of $\mathrm{D}$ ranges between 0 and 1.0 describes the unlimited variety with this indicant, and 1 represents no diversity. It means that a higher grade of $\mathrm{D}$ indicates lower diversity. This is neither intuitive nor logical, so to fix this problem, D is often deducted from 1 to give: Simpson's Index number of Diversity (1-D) (Philippoff and Cox 2013).

The value of this index also ranges from 0 to 1 , but now, a greater grade shows a greater diversity of the sample distribution. This makes more sense. In this case, the index shows the potential that two individuals randomly selected from a sample may belong to different species (Philippoff and Cox 2013).

\section{Socio-economic interviews}

Data on the MTS method, woodland cover alterations, and socio-economic parameters were assigned via examination and interviews with Authorities of the District Forestry Department in charge of the WSFR (Akim Portion), MTS farmers, as well as key informants. Three forest-fringed societies out of 7 were picked out. The societies were Akwansrem (the only community within the conservation), Feyiase (situated in the north-eastern fringe), and Miaso (positioned in the North-western boundary). These selected societies were purposively picked out so that they will match in with the scope and region of the bigger studies. These societies had additionally been actively engaged in the Modified Taungya System since its establishment in Ghana in 2002.

This study utilized purposive sampling and simple random sampling strategies. The purposive sampling was used to pick out a class of peasants, i.e., MTS peasants. Then, within the purposive selection of only MTS peasants, respondents were selected randomly, relying on availability as properly as the willingness to participate. A total sample of 85 respondents was obtained within the limitations of time and different sources. This consisted of 31 MTS peasants in Akwansrem, 25 MTS peasants in Miaso, and 24 MTS peasants in Feyiase. Therefore, 80 MTS peasants that represented $42.5 \%$ of the goal population were interviewed. Additionally, semi-structured interview questionnaires were directed to 3 MTS heads (one from every community sampled), the forest officer in charge of the MTS, and the woodland supervisor of the WSFR (Akim component). Information from these sources served as a perfect tool for balancing the collected data and also the base for the study so that it was no longer entirely on MTS peasants' perceptions. Again, it supplied a reasonable opportunity for the researcher to explain components of the MTS, which are neither usually explicitly defined nor understood.

In each society, a pilot survey including a meeting with the community's chiefs was performed, and the studies' goal was defined. The age, gender, and educational degree of respondents, and other factors probable to steer the scope of data to be acquired were contemplated in the management of the questionnaire. Before administering the questionnaires, the study's goal was thoroughly defined to the respondents with the intention to inspire participation.

\section{RESULTS AND DISCUSSION}

\section{Demographic characteristics of respondents}

A sum of 80 questionnaires was managed to MTS agriculturists. 69 males constituting $86.25 \%$ and 11 females constituting to $13.75 \%$ were interviewed. The academic level of respondents demonstrated a high rate of semiliterates. Approximately $8.8 \%$ of the respondents had no past formal education, whereas 59 constituting about $73.8 \%$ of them have had primary/Junior High School/middle school education. About $65 \%$ of the respondents were married, $5 \%$ were widowed, $6.3 \%$ were divorced/separated, and $21.3 \%$ were single. Table 2 shows other subtle elements. In the meantime, the age groups and occupations of respondents are displayed in Table 3 and Figure 4. 
Table 3 presents the age groups of respondents. The majority $(42.5 \%)$ of the respondents were within the 40-54 age group. This was followed by the 25-39 age group while only about $6.3 \%$ of respondents were below 25 years. Figure 4 shows Respondents' employment (or Alternative Livelihood) other than the MTS. Most of the respondents were peasants engaged in various activities such as cocoa farming, foodstuff farming, fruits and vegetable farming, Poultry farming, and goat raising. Moreover, some few respondents engaged in trading while a few others were into Carpentry, chainsaw operation, and masonry.

\section{Forest cover change analysis}

The provisional analysis in woodland cover alterations exposes two different trends in the WSFR: the period of serious woodland cover loss between 1990 and 2000 followed by the period of decreased woodland cover loss between 2000 and 2010. The region rough calculations showed that during the first period (1990-2000) a total loss of 46.17 ha $\left(0.46 \mathrm{~km}^{2}\right)$ constituting $0.41 \%$ of woodland cover loss while a total of 20.34 ha $(0.20)$ constituting $0.17 \%$ of woodland cover loss in 2000 and 2010 (Table 4).

In addition to the above analysis, the forest cover alteration with regard to the various vegetation cover types was also examined. The exactness evaluation shown in Table 5 exposes an overall exactness of $82.93 \%$.

The forest cover alteration with respect to the different vegetation cover types was useful in noticing specific regions of denudation, regeneration and the contribution of plantation development. Table 6 reveals the region in $\mathrm{km}^{2}$ occupied by a class.

The region evaluation exposed that vast denudation happened during the first decade (1990-2000). Table 6 expressed that a total region of 2764.89 ha $\left(27.65 \mathrm{~km}^{2}\right)$ of closed-canopy forest was lost during the period 1990-2000. Figure 5 also expresses that there was some form of vegetation cover type alteration from closed canopy forest to open canopy forest from 1900 to 2000. For example, while the region of closed canopy forest declined from $60.70 \mathrm{~km}^{2}$ to $33.06 \mathrm{~km}^{2}$, the open canopy forest rose during the same period from $30.31 \mathrm{~km}^{2}$ to $42.17 \mathrm{~km}^{2}$. The most remarkable alteration in forest cover during the first decade was examined within the closed canopy forest, which underwent a percentage decline of as much as $45.547 \%$.

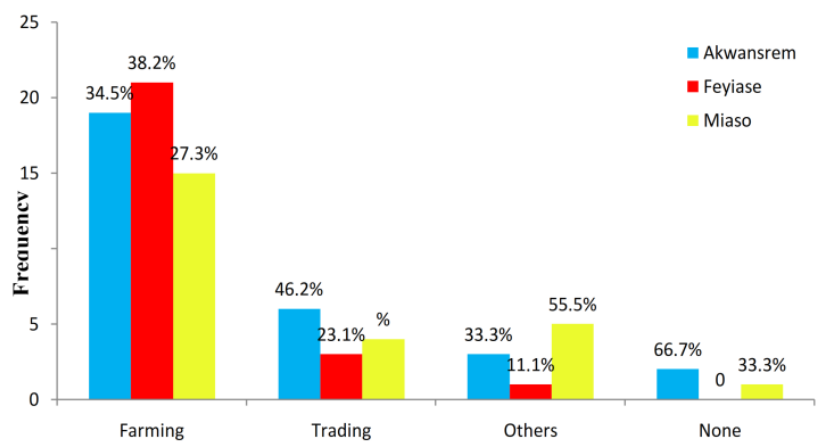

Figure 4. Employment (or alternative livelihood) of respondents other than the MTS

Table 2. Demographic characteristics of respondents

\begin{tabular}{|c|c|c|c|c|c|}
\hline & & $\begin{array}{c}\text { Akwansrem } \\
(\mathbf{N}=\mathbf{3 1})\end{array}$ & $\begin{array}{l}\text { Feyiase } \\
(\mathrm{N}=24)\end{array}$ & $\begin{array}{l}\text { Miaso } \\
(\mathrm{N}=\mathbf{2 5})\end{array}$ & Total \\
\hline & Male & 25 & 23 & 21 & 69 \\
\hline \multirow[t]{2}{*}{ Gender } & Female & 6 & 1 & 4 & 11 \\
\hline & Primary & 24 & 15 & 20 & 59 \\
\hline Educational & Secondary & 3 & 5 & 2 & 10 \\
\hline \multirow[t]{3}{*}{ level } & Tertiary & 0 & 3 & 1 & 4 \\
\hline & None & 4 & 1 & 2 & 7 \\
\hline & Married & 20 & 15 & 19 & 52 \\
\hline \multirow[t]{3}{*}{ Marital status } & Single & 5 & 8 & 4 & 17 \\
\hline & Widowed & 2 & 0 & 2 & 4 \\
\hline & $\begin{array}{l}\text { Divorced/ } \\
\text { Separated }\end{array}$ & 4 & 1 & 0 & 5 \\
\hline
\end{tabular}

Table 3. Age of respondents

\begin{tabular}{lcccc}
\hline Age group & $\begin{array}{c}\text { Akwansrem } \\
(\mathbf{n = 3 1})\end{array}$ & $\begin{array}{c}\text { Feyiase } \\
(\mathbf{n = 2 4})\end{array}$ & $\begin{array}{c}\text { Miaso } \\
(\mathbf{n = 2 5})\end{array}$ & Total \\
\hline Below 25 & 2 & 0 & 3 & 5 \\
$25-39$ & 9 & 6 & 10 & 25 \\
$40-54$ & 15 & 11 & 8 & 34 \\
55 and above & 5 & 7 & 4 & 16 \\
\hline
\end{tabular}

Table 4. Provisional alterations in forest cover within the WSFR

\begin{tabular}{lccc}
\hline Period & $\begin{array}{c}\text { Forest cover } \\
\text { change (ha) }\end{array}$ & $\begin{array}{c}\text { \% change in } \\
\text { forest cover }\end{array}$ & $\begin{array}{c}\text { \% average annual rates } \\
\text { of forest cover change }\end{array}$ \\
\hline $1990-2000$ & -46.17 & -0.41 & -0.03 \\
$2000-2010$ & -20.34 & -0.17 & -0.01 \\
\hline
\end{tabular}

Table 5. Exactness Evaluation Table based on Error Matrix of the pixel-based method

\begin{tabular}{|c|c|c|c|c|c|c|}
\hline Class & $\begin{array}{c}\text { Closed } \\
\text { riverine } \\
\text { vegetation }\end{array}$ & $\begin{array}{c}\text { Open } \\
\text { riverine } \\
\text { vegetation }\end{array}$ & $\begin{array}{c}\text { Dense } \\
\text { shrub/ } \\
\text { herbaceous }\end{array}$ & $\begin{array}{c}\text { Grass/ } \\
\text { herbaceous }\end{array}$ & $\begin{array}{c}\text { Bult up/ } \\
\text { bare regions }\end{array}$ & Sum \\
\hline Closed forest/ riverine vegetation & 13 & 2 & 0 & 0 & 0 & 15 \\
\hline Open forest riverine vegetation & 2 & 16 & 1 & 1 & 0 & 20 \\
\hline Dense shrub/herbaceous & 0 & 1 & 17 & 2 & 0 & 20 \\
\hline Grass/herbaceous & 0 & 1 & 1 & 15 & 3 & 20 \\
\hline Bare/built-up region & 0 & 0 & 1 & 2 & 22 & 25 \\
\hline Sum & 15 & 20 & 20 & 20 & 25 & 100 \\
\hline Exactness & $86.67 \%$ & $80.00 \%$ & $85.00 \%$ & $75.00 \%$ & $88.00 \%$ & \\
\hline
\end{tabular}

Note: Overall Exactness $=82.93 \%$ 
Table 6. Matrix of land cover by class values for the years 1990, 2000 and 2010

\begin{tabular}{lllllll}
\hline Class value & $\mathbf{1 9 9 0}\left(\mathbf{k m}^{\mathbf{2}}\right)$ & $\mathbf{\%}$ & $\mathbf{2 0 0 0}\left(\mathbf{k m}^{\mathbf{2}}\right)$ & $\mathbf{\%}$ & $\mathbf{2 0 1 0}(\mathbf{k m})$ & $\mathbf{\%}$ \\
\hline Closed forest riverine vegetation & 60.70 & 53.09 & 33.06 & 28.91 & 33.47 & 29.27 \\
Open forest riverine vegetation & 30.31 & 26.51 & 42.17 & 36.878 & 42.56 & 37.22 \\
Dense shrub/ herbaceous & 22.28 & 19.48 & 33.87 & 29.62 & 32.97 & 28.83 \\
Grass/ herbaceous & 0.65 & 0.57 & 4.39 & 3.84 & 4.28 & 3.74 \\
Bare surface/ built up region & 0.41 & 0.35 & 0.87 & 0.76 & 1.07 & 0.94 \\
Total & 114.35 & 100 & 114.35 & 100 & 114.35 & 100 \\
\hline
\end{tabular}
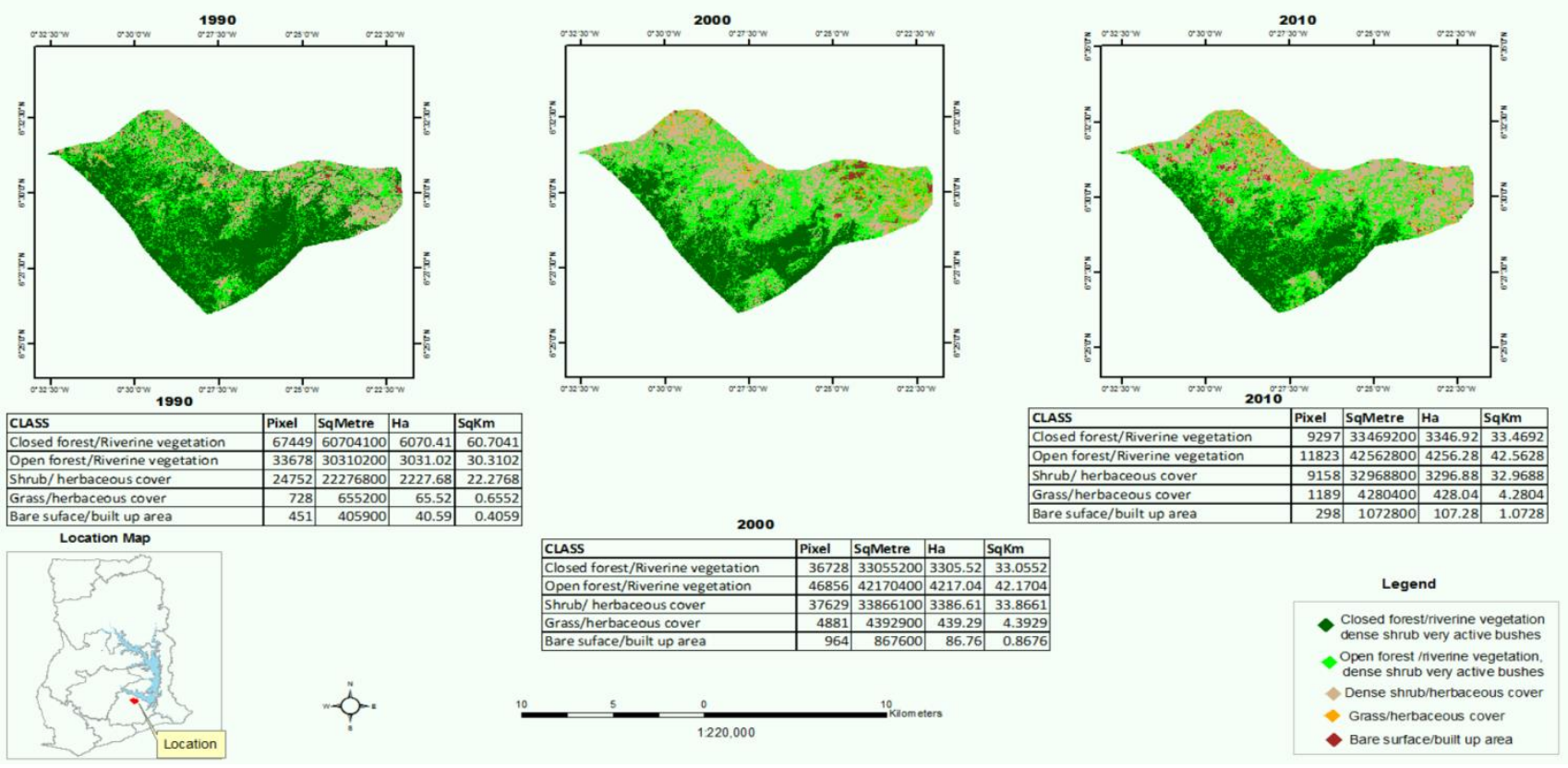

Figure 5. Classified Satellite Image Maps of Worobong South Forest Reserve (1990, 2000 and 2010) (CERSGIS, 2013)

The second decade (2000-2010) recorded a remarkable alteration in provisional patterns of alteration in the regions of both closed and open-canopy forests. Analysis of forest cover for the 2000-2010 period disclosed that the closed forest canopy underwent a region raise of 41.4 ha representing $1.252 \%$ of region regenerated. There was also a raise in the region of open canopy from $42.17-42.56 \mathrm{~km}^{2}$ between 1990-2000 and 2000-2010 respectively. Nevertheless, the raise during the second period was far smaller $(0.93 \%$ alteration $)$ than within the first period (39.13\% alteration) and the most remarkable forest cover type alteration from the 1900-2000 levels was evaluated in the closed canopy cover.

Visual analysis of the scheme of forest cover alteration among the various time intervals was also performed by looking at the spatial variation in forest cover. Figure 5 expresses three different forest vegetation cover maps and their variation in spatial distribution that was produced. From 1990 to 2000, much of the denudation happened from the northern fringes/portions expanding into the center of the conservation. The intensity of denudation was based in the north-eastern corner near the border of the Worobong South Forest Conservations (Kwahu portion) within the
Kwahu South District. There was alteration of the thick closed forest canopy mostly into open forest canopy and to some extent herbaceous cover of grass or shrub. There were also huge patches of bare/built-up regions mustered in the north-eastern portions and fringes of the conservation.

During the period 2000-2010, forest cover loss still mustered within the northern portions of the conservation but with decreased patches of herbaceous cover of grass or shrub. There was a raise in the bare/built-up regions now with smaller patches but mustered within the northwestern portions and fringes of the conservation. However, there was a remarkable development of closed forest canopy especially within the center of the conservation. It could also be noticed that some of the open forest canopies have altered into closed canopy forests. It is projected that between 2010-2020, there will be further development in the closed-canopy forest raising forest cover in the conservation.

\section{The Modified Taungya System (MTS) and forest cover recovery reestablishment}

This section expresses the outcomes from the $100 \mathrm{~m} \mathrm{x}$ $100 \mathrm{~m}$ square transect and people's perception of the 
contribution of the MTS on forest cover development/ recovery.

Results from the $100 \mathrm{~m} \times 100 \mathrm{~m}$ square transect plots.

Table 7-10 indicate diversity of plants in the sampling

\section{Simpson's Index of Diversity}

Results after the estimation of the Simpson's Index (D) and the Simpson's Index of Diversity (1-D) are as Table 11.

Table 7. Natural Forest Samples $(25 \mathrm{~m} \times 25 \mathrm{~m}) \geq 10 \mathrm{~cm} \mathrm{dbh}$

\begin{tabular}{lcccccc}
\hline Species & \multicolumn{7}{c}{ Sample } & & Total \\
\cline { 2 - 7 } & $\mathbf{1}$ & $\mathbf{2}$ & $\mathbf{3}$ & $\mathbf{4}$ & $\mathbf{5}$ & $\mathbf{2}$ \\
\hline Albizia zygia & 2 & 0 & 2 & 0 & 3 & 8 \\
Triplochiton scleroxylon & 2 & 0 & 0 & 3 & 3 & 8 \\
Pitherdeniastrum africanus & 4 & 1 & 3 & 5 & 0 & 13 \\
Nesogordonia paparifera & 5 & 4 & 5 & 4 & 7 & 25 \\
Maesobotrya barteri & 2 & 0 & 0 & 0 & 0 & 2 \\
Oxyanthus speciosus & 1 & 0 & 0 & 0 & 0 & 1 \\
Cola gigantea & 1 & 0 & 0 & 0 & 0 & 1 \\
Bathia nitida & 3 & 0 & 0 & 0 & 0 & 3 \\
Rothmannia longiflora & 2 & 0 & 0 & 0 & 0 & 2 \\
Terminalia superba & 1 & 0 & 0 & 2 & 2 & 5 \\
Milicia excelsa & 1 & 0 & 0 & 0 & 0 & 1 \\
Monodora ternifolia & 1 & 0 & 0 & 0 & 0 & 1 \\
Carapa procera & 2 & 3 & 0 & 0 & 2 & 7 \\
Turraenthus africanus & 2 & 2 & 1 & 0 & 3 & 8 \\
Celtis adolfi-fridericii & 3 & 4 & 0 & 4 & 0 & 11 \\
Parkia sterculia & 1 & 4 & 1 & 0 & 2 & 8 \\
Bridelia microphylla & 0 & 2 & 0 & 0 & 0 & 2 \\
Terminalia ivorensis & 0 & 2 & 1 & 0 & 0 & 3 \\
Ficus exasperata & 0 & 1 & 0 & 0 & 4 & 5 \\
Rauvolfia vomitoria & 0 & 1 & 0 & 0 & 0 & 1 \\
Celtis milbraedii & 0 & 2 & 4 & 5 & 0 & 11 \\
Entandrophragma angolense & 0 & 0 & 1 & 0 & 0 & 1 \\
Strombosia glaucescens & 0 & 0 & 3 & 0 & 2 & 5 \\
Clanitha sp. & 0 & 0 & 1 & 0 & 0 & 1 \\
Erythrina senegalensis & 0 & 0 & 2 & 0 & 0 & 2 \\
Ceiba pentandra & 0 & 0 & 0 & 2 & 0 & 2 \\
Entandrophragma candollei & 0 & 0 & 0 & 3 & 0 & 3 \\
Total & 34 & 26 & 24 & 28 & 28 & 140 \\
\hline & & & & & &
\end{tabular}

Table 8. MTS Plantation Samples $(25 \mathrm{~m} \times 25 \mathrm{~m}) \geq 10 \mathrm{~cm}$ dbh

\begin{tabular}{lcccccc}
\hline \multirow{2}{*}{ Species } & \multicolumn{7}{c}{ Sample } \\
\cline { 2 - 7 } & $\mathbf{1}$ & $\mathbf{2}$ & $\mathbf{3}$ & $\mathbf{4}$ & $\mathbf{5}$ & Total \\
\hline Cedrella sp. & 39 & 48 & 38 & 33 & 35 & 193 \\
Albizia zygia & 3 & 3 & 1 & 2 & 0 & 9 \\
Nesogordonia paparifera & 4 & 3 & 0 & 2 & 2 & 11 \\
Celtis milbraedii & 2 & 0 & 1 & 1 & 2 & 6 \\
Ficus exasperata & 2 & 1 & 0 & 0 & 0 & 3 \\
Triplochiton scleroxylon & 2 & 0 & 0 & 1 & 1 & 4 \\
Ceiba pentandra & 0 & 3 & 0 & 0 & 0 & 3 \\
Ficus sur & 0 & 1 & 0 & 0 & 0 & 1 \\
Terminalia superba & 0 & 2 & 3 & 1 & 0 & 6 \\
Piptadeniastrum africanum & 0 & 0 & 3 & 4 & 2 & 9 \\
Ricimodendrum sp. & 0 & 0 & 1 & 0 & 0 & 1 \\
Bombax blancoanum & 0 & 0 & 1 & 0 & 0 & 1 \\
Terminalia ivorensis & 0 & 0 & 0 & 2 & 0 & 2 \\
Albizia adianthifolia & 0 & 0 & 0 & 0 & 1 & 1 \\
Bathia nitida & 0 & 0 & 0 & 0 & 1 & 1 \\
Total & 52 & 61 & 48 & 46 & 44 & 251 \\
& & & & & &
\end{tabular}

Table 9. Natural Forest Samples $(5 \mathrm{~m}$ x $5 \mathrm{~m}) \geq 1 \mathrm{~cm} \mathrm{dbh}$

\begin{tabular}{lcccccc}
\hline \multirow{2}{*}{ Species } & \multicolumn{7}{c}{ Sample } \\
\cline { 2 - 7 } & $\mathbf{1}$ & $\mathbf{2}$ & $\mathbf{3}$ & $\mathbf{4}$ & $\mathbf{5}$ & Total \\
\hline Uapaca togoensis & 2 & 0 & 0 & 0 & 0 & 2 \\
Bathia nitida & 6 & 15 & 13 & 6 & 8 & 48 \\
Pentaclethra macrophylla & 15 & 10 & 0 & 0 & 7 & 32 \\
Turraenthus africanus & 2 & 2 & 0 & 3 & 0 & 7 \\
Xanthoxylum gilletii & 1 & 0 & 0 & 0 & 4 & 5 \\
Pitherdeniastrum africanus & 2 & 0 & 0 & 0 & 0 & 2 \\
Nesogordonia paparifera & 1 & 0 & 0 & 0 & 3 & 4 \\
Cedrella sp. & 0 & 1 & 0 & 3 & 0 & 4 \\
Oxyanthus speciosus & 0 & 2 & 1 & 0 & 0 & 3 \\
Microdesmis puberula & 0 & 3 & 5 & 0 & 0 & 8 \\
Tabernaemontana crassa & 0 & 1 & 0 & 0 & 0 & 1 \\
Maesobotrya barteri & 0 & 2 & 0 & 0 & 0 & 2 \\
Napoleonaea vogelii & 0 & 1 & 0 & 0 & 0 & 1 \\
Carapa procera & 0 & 2 & 0 & 0 & 0 & 2 \\
Heisteria sp. & 0 & 0 & 4 & 3 & 0 & 7 \\
Connaraceae sp. & 0 & 0 & 3 & 0 & 0 & 3 \\
Albizia zygia & 0 & 0 & 1 & 7 & 0 & 8 \\
Celtis milbraedii & 0 & 0 & 4 & 5 & 0 & 9 \\
Ficus exasperata & 0 & 0 & 0 & 0 & 3 & 3 \\
Cola milleni & 0 & 0 & 0 & 4 & 4 & 8 \\
Parkia bicolor & 0 & 0 & 0 & 4 & 0 & 4 \\
Total & 29 & 39 & 31 & 35 & 29 & 163 \\
\hline
\end{tabular}

Table 10. MTS plantation samples $(5 \mathrm{~m} \times 5 \mathrm{~m}) \geq 1 \mathrm{~cm} \mathrm{dbh}$

\begin{tabular}{lcccccc}
\hline & \multicolumn{7}{c}{ Sample } \\
\hline Species & $\mathbf{1}$ & $\mathbf{2}$ & $\mathbf{3}$ & $\mathbf{4}$ & $\mathbf{5}$ & Total \\
\hline Cedrella sp. & 5 & 5 & 6 & 4 & 5 & 25 \\
Cola millenii & 11 & 4 & 0 & 18 & 15 & 48 \\
Bathia nitida & 5 & 6 & 0 & 0 & 7 & 18 \\
Triplochiton scleroxylon & 3 & 0 & 3 & 6 & 0 & 12 \\
Terminalia superba & 3 & 0 & 1 & 1 & 0 & 5 \\
Terminalia ivorensis & 0 & 4 & 3 & 0 & 0 & 7 \\
Pentaclethra macrophylla & 0 & 5 & 0 & 0 & 4 & 9 \\
Ficus exasperata & 0 & 1 & 0 & 0 & 0 & 1 \\
Microdesmis puberula & 0 & 0 & 2 & 0 & 0 & 2 \\
Celtis milbraedii & 0 & 0 & 0 & 1 & 0 & 1 \\
Petersianthus macrocarpus & 0 & 0 & 0 & 0 & 5 & 5 \\
Total & 27 & 25 & 15 & 30 & 36 & 133 \\
\hline
\end{tabular}

Table 11. Results of the Simpson's Index of diversity

\begin{tabular}{lcc}
\hline Transect & D & 1-D \\
\hline Natural Forest $(25 \mathrm{~m} \times 25 \mathrm{~m})$ & 0.068 & 0.93 \\
MTS Plantation $(25 \mathrm{~m} \times 25 \mathrm{~m})$ & 0.595 & 0.41 \\
Natural Forest $(5 \mathrm{~m} \times 5 \mathrm{~m})$ & 0.138 & 0.86 \\
MTS Plantation $(5 \mathrm{~m} \times 5 \mathrm{~m})$ & 0.196 & 0.80 \\
\hline
\end{tabular}

Table 12. Respondents' view on the contribution of the MTS to forest cover recovery reestablishment

\begin{tabular}{lcccc}
\hline Response & Akwansrem & Feyiase & Miaso & Total \\
\hline Yes & 22 & 19 & 20 & 61 \\
No & 5 & 4 & 4 & 13 \\
N/A & 4 & 1 & 1 & 6 \\
\hline
\end{tabular}


The result from Simpson's Index of diversity (Table 11) showed that the natural forest is more varied in terms of species copiousness and evenness/relative richness than the MTS plantation. For the $25 \mathrm{~m}$ x $25 \mathrm{~m}$ samples, Diversity values (1-D) of 0.93 and 0.41 were recorded for the natural forest transect and the MTS plot respectively. Although, stem calculation for the later was higher than the former, copiousness (number of individual tree species) and evenness (relative richness) was relatively higher for the former. This is evidenced by comparing Tables 7, 8, 9 and 10. For instance, by comparing the number of species in Table 7 with that in Table 8 , the result shows that the natural forest recorded 8 tree species which was higher than the MTS plantation. Examples of tree species lacking in the MTS plantation comprise Monodora ternifolia, Carapa procera, Turraenthus africanus, Celtis adolfifriderici, and Parkia sterculia. The most abundant tree species in the natural forest sample was Pitherdeniastrum africanus (13).

Equivalently, by comparing the $5 \mathrm{~m} \times 5 \mathrm{~m}$ samples (Tables 9 and 10), it showed that the natural forest recorded more tree species (24) which was higher than the MTS plantation (14). Yet, the most abundant tree species for the natural forest was Bathia nitida followed by Pentaclethra macrophylla, while for the MTS plantation it was Cola millenii followed by Cedrella sp. and Bathia nitida. Furthermore, the average number of trees per sampled plot was counted by dividing the total number of stems for each community by the number of samples. Tables 7 and 8 show the number of stems per plot sampled within the $25 \mathrm{~m} \times 25$ $\mathrm{m}$ transect squares, the average number of trees per sampled MTS plot was 50 while that of the natural forest was 28 .

Views from peasants concerning the Modified Taungya System and forest cover recovery reestablishment

To calculate if the MTS has had contribution to forest cover recovery reestablishment, respondents were asked to answer yes or no. Table 12 shows their responses.

Most of the respondents $(76.3 \%)$ noted that the MTS has had contribution to forest cover recovery reestablishment while a few others have responded otherwise, and the others were not sure. However, interview with the MTS heads confirmed that the MTS has really contributed to forest cover recovery reestablishment in the WSFR. Both respondents and MTS leaders in all communities agreed that about 600-800 trees were grown every year.

\section{Plot allocation and responsibilities of farmers under the Modified Taungya System}

Farmers were questioned if they took part in MTS as individuals or as a group. If the peasants were a member of a group, they were questioned if they had routine interactions with supporting institutions, in order to try and to get an idea of the involvement of the peasants in the implementation process and to find out the manner in which information was communicated to them and by them. The result signified that there was a Community MTS Committee in all three communities who relay information to the peasants. The setting up of these committees is part of the plans put in place in order to give the community a voice and an arena of discussion and to make sure the compliance of all actors engaged in the MTS scheme. The committee is set up of those members of the society who are picked out after putting themselves forward and is headed by representatives from the Forest Services Division (FSD). It is the committees that allocate the downgraded lands to peasants. They also monitor the performance of peasants and FSD as well as resolve frictions and help implementation of sanctions if necessary.

Most peasants had been engaged in the MTS since its inception in 2002. Plots had been allocated annually, except for 2009 in Akwansrem and 2012 in Feyiase. Most peasants reported having being allocated plots roughly equivalent to half to an acre, each year that land was allocated. For some peasants, the precise measurement was quite difficult to tell, since different local peasants utilized different means of measuring. What became clear however was that the chiefs of the Modified Taungya Committee in all villages had been allocated substantially more land (about two or three acres, each year of allocation) than other members of the committee.

Farmers were also questioned about roles in the MTS with the view that knowledge and full understanding of their roles is remarkable in order for all the peasants to effectively contribute to the scheme's success. From the study, all respondents were keen to state that they needed to plant and then take care of the tree species and the crops. Some mentioned the need to weed and the need to maintain the trees and to replace seedlings if there is mortality, others mentioned the responsibility in the dry season is to protect the trees from fire. There was an overwhelming feeling of the importance of generally keeping an eye on the trees, be it in the instance of fire, chainsaw operation, theft or encroachment.

\section{Tree species and agricultural crops cultivated under the Modified Taungya System}

Information gathered from respondents including MTS heads and Forest Authorities signified that the tree species peasants planted depended on what seedlings were available to them. According to the MTS peasants, this somewhat restricted their choices. This is because peasants were interested in planting fast-growing species like Teak, Cedrella, and Ofram (Terminalia superba). Cedrella sp. was the most commonly grown species by peasants $(87 \%)$. However, $12 \%$ of peasants in Feyiase reported planting indigenous Wawa (Triplochiton scleroxylon), while $15 \%$ of peasants in Miaso planted slow-growing mahogany (Khaya grandifoliola).

Furthermore, the products harvested from the land inbetween the tree seedlings were taken into consideration. It was identified that almost all of the staples of the Ghanaian diet were grown. All MTS peasants planted plantain. Other crops included maize (47.5\%), cocoyam (41.3\%) and vegetables $(55 \%)$. The vegetables included garden eggs, onions, tomatoes, peppers, okra, etc. However, cassava was not allowed at the initial stages of planting and was only allowed when the tree seedlings had rooted sufficiently (Table 13). 


\section{Motivation for participating in the MTS}

Table 14 shows the reason given by peasants for participating in the MTS program. Out of the reasons listed, access to farmlands, increased access to food crops and improved livelihoods were identified from all three communities as the main interests for participating in the MTS. However, apprehension for the environment and livelihoods seem to be of less interest to the respondents.

\section{Standard of living and livelihood benefits from the MTS}

The Farmers were questioned about how the MTS is contributing to their livelihoods. Of the respondents in Akwansrem, $63.3 \%$ saw the MTS plot as a reliable source of livelihoods, hence a major livelihoods option, whereas $36.6 \%$ saw it as a safety net. In Feyiase, 54\% saw it as a reliable source of livelihoods while $44 \%$ saw it as a safety net. In Miaso $60.0 \%$ and $36 \%$ saw it as a reliable source of livelihoods and a safety net respectively (Table 15).

Farmers who sold their farm products were questioned to state the average livelihoods they have been livelihood from their MTS farm plots. The average livelihoods per season were as follows (Table 16). This table showed that most peasants who sold their farm produce earn between GH' 500- GH 1,000 every season. However, some peasants earned above GH' 1,000 . In order to try to establish any alterations in their standard of living, peasants were questioned to describe their ease of getting the following: farm produce, children's education, putting up a building, household's daily care and access to land for farming since the introduction of MTS. In all three communities, majority of peasants reported that it was now easier to access farm produce and land for farming. The percentage of peasants in Akwansrem reporting on their ability to afford children's education was much lower than that of Feyiase and Miaso. Approximately a third of peasants in Akwansrem and Feyiase reported putting up a building was easier. It was reported that the provision of the household's daily care was easier for the majority of the peasants. The peasants, who had not seen an improvement, reported that the level of ease to access the various options remained the same (Table 17).

At the current stage of MTS, it is clear that the MTS is affecting positively people's lives; the livelihoods generated from the agricultural crops are enabling peasants to achieve an increased standard of living.

The interview with the MTS chiefs showed that smallscale subsistence farming with crops like maize, cassava, cocoyam, and plantain is the main provider of livelihoods, along with NTFPs that can be harvested from the forest. They confirmed that they and the peasants can make a reasonable livelihood from the agricultural crops acquired from the MTS, since the crops belong to them and they gather all the revenue from their sale. On the occasions when they may have a surplus, they can sell products in the local markets. At other stages, the crops are utilized for livelihood, and hence form a non-cash component of their livelihoods. However, apprehensions were raised at the deficiency of diversity in the livelihood portfolios of the community, in that it is mainly dependent on crops and with the threats of land degradation and wildfire, it means that it is not a very secure option. The objective of the MTS scheme is not only to increase the livelihoods of the autochthonous rural population within the surroundings of the plantation sites but also to broaden the plantation sites in an economically and ecologically sound manner. By further interaction with peasants and MTS heads, it appeared to be difficult to achieve factual data on the extent to which the MTS contributed to people's livelihoods. Not just because of a deficiency of proper records, but moreover because so little is ever transformed into a physical monetary value (i.e., much is pettily traded, or non-cash livelihoods).

Table 13. Crops cultivated under the MTS

\begin{tabular}{|c|c|c|c|c|}
\hline \multirow{2}{*}{$\begin{array}{l}\text { Agricultural } \\
\text { crop }\end{array}$} & \multicolumn{4}{|c|}{ Number of respondents } \\
\hline & Akwansrem & Feyiase & Miaso & Total \\
\hline Plantain & 31 & 24 & 25 & 80 \\
\hline Maize & 16 & 9 & 13 & 38 \\
\hline Cocoyam & 10 & 13 & 10 & 33 \\
\hline Vegetables & 17 & 12 & 15 & 44 \\
\hline Cassava & 14 & 13 & 16 & 43 \\
\hline
\end{tabular}

Table 14. Reasons for participating in the MTS

\begin{tabular}{lccc}
\hline Reason & \multicolumn{3}{c}{ Number of respondents } \\
& Akwansrem & Feyiase & Miaso \\
& $(\mathbf{N}=\mathbf{3 1})$ & $(\mathbf{N = 2 4 )}$ & $(\mathbf{N = 2 5})$ \\
\hline Access to farm land & $24(80 \%)$ & $20(80 \%)$ & $21(84 \%)$ \\
Access to food crops & $21(70 \%)$ & $22(88 \%)$ & $18(72 \%)$ \\
Income & $3(10 \%)$ & $5(20 \%)$ & $2(8 \%)$ \\
Apprehension for the & $13(43.3 \%)$ & $5(20 \%)$ & $8(32 \%)$ \\
environment & & & \\
Improved livelihood & $23(76.6 \%)$ & $19(76 \%)$ & $20(80 \%)$ \\
\hline
\end{tabular}

Table 15. The MTS as an alternative source of livelihoods

\begin{tabular}{llll}
\hline \multirow{2}{*}{ Contribution to income } & \multicolumn{3}{c}{ Frequency } \\
\cline { 2 - 4 } & Akwansrem & Feyiase & Miaso \\
\hline Reliable source of livelihoods & 19 & 13 & 15 \\
Safety net & 11 & 11 & 9 \\
\hline
\end{tabular}

Table 16. Average livelihoods from the sale of farm produce

\begin{tabular}{lccc}
\hline \multirow{2}{*}{ Income (Cash in GHC) } & \multicolumn{3}{c}{ Frequency } \\
\cline { 2 - 4 } & Akwansrem & Feyiase & Miaso \\
\hline Below 500 & 6 & 5 & 2 \\
$500-1,000$ & 5 & 8 & 6 \\
$1,000-1,500$ & 3 & 2 & 4 \\
$1,500-2,000$ & 2 & 1 & 1 \\
2,000 and above & 2 & 0 & 1 \\
\hline
\end{tabular}

Table 17. Effects of MTS on household's ability to afford various livelihoods components.

\begin{tabular}{lccc}
\hline Consequence/effect & Akwansrem & Feyiase & Miaso \\
\hline Household's daily care & 21 & 19 & 22 \\
Access to farm produce & 23 & 20 & 19 \\
Children's education & 8 & 13 & 15 \\
Putting up a building & 10 & 9 & 6 \\
\hline
\end{tabular}




\section{Farmers' perception of the benefit-sharing in the MTS Scheme}

In general, peasants were satisfied that forty percent $(40 \%)$ was a suitable amount for the peasant to receive but the method in which the revenue from the sale of the timber grown within the MTS will be shared was a remarkable consideration. This is because the agreement about the revenue division is not clear. Globally, peasants believed that the money from the sale of timber would be divided according to the amount of land or trees owned by the respective villagers. Most peasants $(83 \%)$ suggested that the revenue should be divided up according to the width of cultivated land or the total of trees they had planted. Others had little idea and hoped the authorities would divide the money up fairly.

However, 53\% of the respondents at Akwansrem, 67\% at Feyiase, $48 \%$ at Miaso signified at present that there was no mechanism in place and that they were unaware of the operation of the mechanism and the division of the money. Majority $(87 \%)$ of the respondents desired some sort of loan or part payment to maintain the farm and buy farm logistics. This is because peasants reported spending a lot of time in planting and conservation since they do not have money to hire laborers.

Results from the interview with the MTS chiefs about peasants' understanding of the MTS also disclosed similar views. MTS chiefs' understanding of the future of the MTS is uncertain. They signified that the confidence of the peasants in the MTS is impeded by a deficiency of clarity and certainty in the scheme and how the revenue will be divided up as promised. Without the release of funds for some years now, peasants' deficiency of capital to invest in planting, pegging, weeding, and conservation of the MTS. They also reported that deficiency of documentation signed and held by the communities in respect of the agreement had led to a feeling of insecurity.

Furthermore, there is a worry of fire, and there is a worry that if a peasant dies, the livelihoods due may not be put into the right hands. There is a general worry that illegal loggers may come and harvest the trees when they are mature enough and then the peasant would receive no money. There is also worry of devastation of the forests and therefore, the disturbance of the livelihoods provided by NTFPs. Delays in the allocation of the plots of land to be planted are sometimes realized as that there had been a tendency of seedlings to die or to be infested by insects. There is also the inevitable report of the inequitable distribution of the land by MTS chiefs, and some had to travel long distances in order to reach their plots. Forest officials reported the idea of thinning as a means for the peasant to generate livelihoods; once the trees are starting to grow themselves, some need to be cut down in order to permit adequate space and light for the others to grow.

\section{Threats to the MTS}

Farmers were questioned what they felt were particular menaces to the scheme, since menaces and fears affect participation. The result is summarized in Figure 7.

The result signified that most peasants $(67.5 \%)$ were frightened of fire and its impact on the scheme's success.
For the most part, it was a wildfire that people feared, but several peasants voiced apprehensions that deliberately starting fires was also a problem. It was noticed to some extent that envy existed between communities, particularly when one community is picked out to be engaged in a particular scheme while a neighboring village is not chosen. With regard to other fears or menaces to the scheme, 39 peasants raised apprehension at the prospect of illegal chainsaw lumber operations being performed in the MTS plots. Others raised apprehension that some peasants putting more effort into the MTS scheme than others could be a menace to the scheme as a result of weeds spreading from lazy peasants' plots. A number of peasants also signified that they neither had nor could afford the equipment, for example, proper rubber boots, cutlasses, and raincoats, which sometimes infringes upon their ability to be able to farm.

\section{Sustainability of the MTS Scheme}

Suggestions made by respondents showed that the scheme can be sustainable through the enactment and enforcement of laws, education, and clarity of the scheme and its benefits, percentage share of revenue periodically. However, most peasants noted that there should be some percentage payment of their benefits from the timber before harvesting time is due. Some peasants explained that this will help reduce bulk payment at the time of harvesting matured trees. All the MTS chiefs agreed with the peasants noting that the pre-harvest benefit from the timber would serve to attract and motivate peasants to continuously invest labor. Table 18 shows the suggestions made by the MTS peasants.

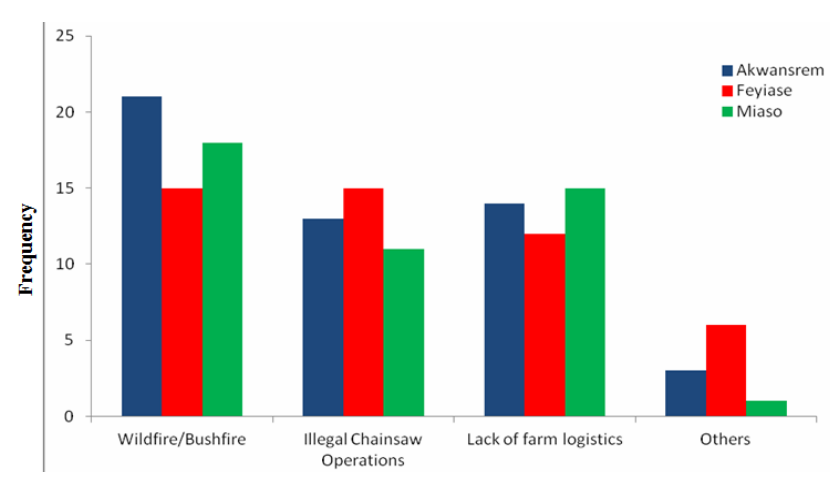

Figure 7. Threats to the MTS

Table 18. Suggestions on how to make the Modified Taungya System sustainable

\begin{tabular}{lcccc}
\hline \multirow{2}{*}{ Suggestions } & \multicolumn{5}{c}{ Frequency } \\
\cline { 2 - 5 } & Akwansrem & Feyiase & Miaso & Total \\
\hline Education & 16 & 14 & 16 & 46 \\
Enactment of laws & 18 & 14 & 15 & 47 \\
Periodic benefits from pre- & 20 & 15 & 18 & 53 \\
harvested timber & 12 & 7 & 9 & 28 \\
Enforcement of laws & 2 & 0 & 1 & \\
2,000 and above & & &
\end{tabular}




\section{Discussion}

Monitoring and assessing forest cover change of the WSFR

The researcher calculated the forest cover alteration of the WSFR from 1990 to 2010. Many studies have shown the alarming rate of forest cover loss in Ghana. According to Opoku (2006), forest cover loss between 1900 and 1990, was from 1.6 million ha to 8 million ha. Similar studies done elsewhere have signified that tropical forests are being cleared, burned, logged, fragmented and overhunted on scales that deficiency of historical precedent (Laurance and Bierre-gaard 1997). Again, satellite images of statemanaged forest conservations taken in 1990 and 2000 reveal rapid denudation within most conservations (Ghana Forestry Commission 2002). The results of this study showed a similar situation between 1990 and 2000 (Figure 5).

However, the results of the forest cover alteration analysis showed different trends as well as variations in the rate of forest cover alteration between the decades considered. The forest region estimation showed that vast denudation happened during the first decade (1990-2000) resulting in a vegetation cover type alteration from closedcanopy forest to open canopy forest during 1900-2000. Similarly, a study performed by Ayivor (2007) in the Digya National Park signified a rapid alteration of the closed forest cover into open forest and grassland. The reason for the degradation within the closed canopy forest during the first decade (1990- 2000) could be that it was destroyed by illegal logging, increased agricultural activities and encroachment by human settlements as shown in this study.

The most remarkable forest cover type alteration for the second decade (2000-2010) was studied in the closed canopy cover. Thus, while there was a decline in forest cover during the first decade, there was, however, a remarkable increase in forest cover during the second decade (Table 4, Figure 5). The increase in region of closed forest canopy was more pronounced at the center of the conservation. It could also be noticed that some of the bare regions and open forest canopy had been changed into closed-canopy forests. Forest regeneration/recovery reestablishment studies have signified that forest vegetation recovery can usually be sped up by planting trees (Holl 2013) and that forest plantation, though generally intended for the production of timber, increases the total region of forest worldwide (Lund 2006). The region improvement within the closed forest canopy during the second decade (2000-2010) could, therefore, be attributed to success of the MTS projects in the WSFR.

\section{The contribution of the MTS to forest cover recovery reestablishment}

Reforestation is the primary goal of the NFPDP. Among the aims of establishing the 1994 Forest and Wildlife Policy was to ensure forest recovery reestablishment and sustainable utilization of forest founts (NFPDP 2003). Advancement made so far in forest cover within the WSFR can be said to be remarkable. For the $25 \mathrm{~m}$ x $25 \mathrm{~m}$ plot samples, Diversity values (1-D) of 0.93 and 0.40 were recorded for the natural forest transect and the MTS plot respectively. This signifies that multifariousness was higher within the natural forest. However, the average number of tree stems for the latter was 50 while that of the former was 28. Meanwhile, most peasants reported that between $600-800$ trees are planted on 0.8 ha, annually. This means that downgraded regions within the conservation are being restored through the MTS Scheme. In a similar study done in the Offinso district in the Ashanti Region of Ghana, a total of 10,181 ha of downgraded forest lands were planted from 2002 to 2007; and this led to the recovery reestablishment of such lands. (Ghana Forestry Commission 2001).

According to Ghana Poverty Reduction Strategy (GPRS) Report, plantation cover was to broaden from the 2002 level of 20,000 ha to 60,000ha by end of 2008 (GPRS 2005). In 2004 alone, the GPRS showed a cumulative figure of 58,726 ha, thus exceeding the 2008 targets. The GIS and RS analysis in this study also showed that the second period (2000-2010) recorded a remarkable development of closed forest canopy, mostly from the alteration of the bare regions and open forest canopy to close canopy forest. According to Holl (2013), forest regeneration/recovery reestablishment studies done have signified that natural regeneration of downgraded forests may occur but at a very slow pace, biodiversity recovery can usually be quickened by planting some climax forest tree species, especially large-seeded, poorly dispersed species. It is not feasible to plant all the tree species that may have formerly grown in the original primary forest and it is usually unnecessary to do so (Holl 2013). In another study done in Gainesville, it was noted that forest plantations, though generally intended for the production of timber, increase the total region of forest worldwide (Lund 2006). The improvement of the region with a closed forest canopy during the second decade (2000-2010) could, therefore, be attributed to the success of the MTS projects in the WSFR.

Additionally, the Programs on Forests (PROFOR 2011) claimed a forest recovery reestablishment success story performed in Ghana by the Community Collaborative Recovery Project in the Pamu Berekum forest region situated in the Brong-Ahafo Region of Ghana. Plantations included Tectona grandis and Cedrella odorata, also mixed with Terminalia superba, Terminalia ivorensis, and Cedrella odorata (PROFOR 2011). This current study showed that the MTS plantations grow similar species, especially Cedrella sp. Forest recovery reestablishment is therefore expected to be more successful by the end of the next decade.

An increase in forest cover led to the decrease of farmlands around the forest conservations. This will potentially decrease the crop yield of farmlands in this region, though the aim of decreasing forest degradation and raising forest cover under the NFPDP could be said to be achieving its targets within the WSFR (GPRS 2005).

\section{Benefits of the MTS to farmers livelihoods}

The Forest of Ghana (both on and off conservation) provides both direct and indirect livelihoods benefited to the entire population (Blay et al. 2006). In the fringes of the forest, livelihoods are built nearly entirely on the use of local natural founts, be it from farming, forestry, chainsaw operations, charcoal production, or hunting and gathering (Marfo et al. 2002). 
The results of the study showed that majority of all MTS peasants cultivated plantain as major crop while a number of them cultivated maize, cocoyam, and vegetables in different quantities. In a related study at Asuboi and Kunsu farming communities in Ghana, Amissah (2009) signified that majority of Taungya peasants cultivated plantain and cocoyam as major crops while cassava, vegetables, groundnut, and yam were cultivated as minor crops. This indicates that the program was beneficial in reducing poverty of Taungya peasants. The intervention for overcoming subsistence poverty lies in providing sufficient food to meet the family requirement (O'Donnell 1992).

Reports from the Forest Service Division (FSD) also indicate that MTS made substantial contributions to food production, particularly in plantain and maize crops in 2003 and 2004, although the report did not provide figures to quantify crop production (FPDC 2002). Records at the Ministry of Local Government and Rural Development (MLGRD) (2006) also showed that in 1998 the Mankranso district's average yield per hectare for plantain, cocoyam, cassava, and maize was higher than the regional figures. There is no doubt that MTS had improved crops production in the study region and subsistence poverty can be said to have been reduced for peasants.

According to Webster (1990), Basic needs strategy adopts direct assistance to meet basic needs through employment and providing capital for investment in agriculture to improve livelihoods. Although, majority of the MTS peasants were employed while a few of them were unemployed previously, majority of the respondents saw the MTS as a great alternative source of employment and for that matter livelihood (Table 14 and Table 15). This was confirmed by those who were engaged in the sale of their crops (Table 14 and Table 15). The MTS chiefs also confirmed that small-scale subsistence farming with crops like maize, cassava, cocoyam, and plantain is the main provider of livelihoods, together with NTFPs that can be harvested from the forest. They further emphasized that the peasants can make a reasonable livelihood from the agricultural crops since the crops belong to them and they gather all the revenue from their sales. Other sources of livelihoods apart from the $40 \%$ share in trees grown are from site preparation, supply of seedling stocks, nursing and planting of seedlings as well as pegging (Marfo 2009). The financial contributions, technical assistance, and provision of planting materials to peasants increased the financial and physical capital of MTS peasants (FPDC 2002).

Furthermore, in all three communities, majority of peasants reported that it was now easier to access farm produce and land for farming. Other peasants reported putting up a building, household's daily care as well as provision of children's school fees was easier (Table 17). This means that both physical and social capital of peasants was improved. These reasons are consistent with the reasons that the peasants raised for participating in the MTS scheme. These reasons were: access to farmlands, increased access to food crops and improved livelihoods. Others were concern for the environment and livelihoods. Although apprehension for the environment was not mentioned by a number of them, it was however clear from the interactions that the peasants were unhappy with the degradation that was taking place and hence desired that something was done about it. It must also be noted that livelihoods are rooted in the above reasons because access to farmland and food are all factors that lead to acquiring livelihoods. In a similar project in Pamu Berekum, successes attributable to the project included increased food production by the local peasants engaged in the project, which translated into increased livelihoods to the peasants and improvement in rural subsistence (PROFOR 2011).

The result of this study is also consistent with the third and fourth objectives of the MTS which are also consistent with the overall objectives pursued by the NFPDP discussed in the literature review. At the current stage of MTS it is clear that the MTS is having a positive effect on people's lives; the livelihoods generated from the agricultural crops are enabling peasants to achieve an improved standard of living.

\section{Threats to the MTS}

Denudation is caused by the exploitation of natural founts including logging, agriculture, biofuel production, and wildfires. For instance, in the transition region of Ghana, annual bush fires cause havoc to forest founts resulting in large tracts of conservations being burnt to the ground. In 1996, there were 127 incidences of bushfires in four major forest regions (Eastern, Ashanti, Western, and Brong Ahafo) leading to a loss of $27 \mathrm{~km}^{2}$ (Ghana Forestry Commission 2002). The results of this study signified that wildfires, illegal logging, and deficiency of proper conservation of MTS farms plots are some menaces to the MTS. For the most part, it was a wildfire that people feared and the dramatic impact it would have on the scheme's success; especially, deliberately started fires. It was reported that to some extent, jealousy existed between communities, particularly when one community is picked out to be engaged in a particular scheme while a neighboring village is not chosen. This could mean that forest-fringed communities have identified tremendous benefits with the MTS scheme and those not engaged wished that their community was chosen for the program.

With regard to other fears or menaces to the scheme, some peasants raised apprehensions with the prospect of illegal chainsaw lumber operations being performed in the MTS plots. In a study done in the Atiwa district, Seneadza (2010) and Anane (2003) noted that forest cover loss was mainly caused by agricultural activities, illegal mining, illegal logging, and the establishment of infrastructure as a result of population explosion and the requirement for economic and social development. Similarly, clearing forests for the production of biofuel are causing major apprehension, as experts contend that it has a remarkable negative impact on forests without doing much to decrease greenhouse gas emissions (World Bank 2010). The result of the study signified that illegal logging still exists within the WSFR (Figure 7) and these activities wipe the natural forest canopy and subsequently bring certain flora and fauna species in the forest to endangered situations (Seneadza 2010). 
Other apprehensions from the respondents were the lazy attitude of some peasants as well as deficiency of logistics (Figure 7). It was evident that some peasants seem to put more effort into the MTS scheme than others and hence posing as a challenge to the scheme. There were also a number of peasants who neither had nor could afford equipment, for example, proper rubber boots, cutlasses and raincoats, which sometimes infringes upon their ability to be able to farm. In a similar study in forest-fringe communities of the Tano Offin Conservation, it was emphasized that some peasants engaged in the MTS scheme, allowed weeds to spread on their plots (Ledger 2009).

Furthermore, apprehensions were raised at the deficiency of diversity in the livelihood options of the populations in and around the WSFR, in that there is over reliance on crops and with the potential for land degradation and wildfire, that option is not very secure. The purpose of the MTS scheme is not only to improve the livelihoods of the local rural population within the surroundings of the plantation sites but to also broaden the plantation sites in an economically and ecologically sound manner (Ledger 2009).

In relation to livelihoods, the result of the study showed that most peasants were enjoying both cash and non-cash livelihoods (Table 16). The challenge to them was the sustainability of the livelihoods they enjoyed. They were particularly worried about available plots in the future. Thus, if almost all downgraded portions of the conservation close to them are restored with planted trees, then there would be no land for farming and hence no livelihoods in the future. Nevertheless, peasants have a $40 \%$ share in the timber species planted.

Finally, Acheampong et al. (2016) in his work entitled "Management of Ghana's MTS: challenges and strategies for improvement" noted the following as MTS management challenges: Timelapse in livelihoods from canopy closure to timber harvesting, insecurity due to deficiency of signed agreement, deficiency of clarity in the benefit-sharing agreement, untimely provision of seedlings and distance from the community to MTS plot. Apart from timely provision of seedlings, all the other points were identified in this research as challenges/menaces to the MTS. However, there is also the report of the inequitable distribution of the land. This means that management of the MTS Scheme must take these issues seriously.

\section{Sustainability of the MTS}

The 1994 Forest and Wildlife policy of Ghana aims to maintain environmental quality and perpetual flow of advantages to all society (Opoku 2006). The World Bank has conjointly recognized that focusing solely on protection misses the chances for poverty reduction and developed administration and conservation of productive forest (World Bank 2005). In accordance with Mwavu and Witkowski (2008), societies have rules to keep the collective welfare from hazardous actions performed by individual members of society. However, a winning implementation of those rules relies on an enabling environment. The will of all stakeholders to support them may be a reflection of societies' aware and unaware ideologies entrenched through history (Tankpa 2010).

The Institute of Statistical, Social and Economic Analysis (ISSER 2008) declared that occasionally the interests of autochthonous people, who depend on the forest for their subsistence, are immolated for the economic advantage that is reaped from logging trees for timber export. With this method, the Forestry Policy of the Republic of Ghana, meant for the tenable management of the forest, is ignored. The government's objective of rising overseas exchange by exploiting forest founts (such as lumbering), plantation agriculture, and mining have usually given benefits for foreign countries and the corporations entangled within the trade of timber, money crops, and mineral founts (Southgate et al. 1991). There are rules that explain where, when, how, and how much timber could be extracted, however, they usually gave no effective enforcement in the Republic of Ghana (Hansen et al. 2009).

The 1992 Rio de Janeiro Summit created an interesting impact on Ghanaian environmental awareness resulting in the adoption of the 1994 Forest and Wildlife Policy. The design of this policy aroused the government's responsibility to manage the selected protected regions on a more tenable basis (Ayivor 2007). Forest conservation has a huge profit not solely in economic terms to society but also to the global ecosystem everywhere because of direct and indirect services offered by forest founts. Equivalently, all respondents during this study understood the necessity to adopt tenable ways in the administration of the MTS layout (Table 18). The recommended measures involved authorization and practice of laws to secure the MTS plots and also the conservation, to the clarity of the MTS and its advantages through education, and to share a percentage of revenue occasionally.

According to Sayer (2004) in "The recovery of forest biodiversity and ecological values in Asia," vast investments are being created in the development of tree plantations on downgraded land in Asia. These enthusiasts are usually politically driven and yearn to attain both economic and environmental advantages. Nevertheless, the dearth of clearness regarding the precise objectives of those arrangements implies that they usually fail to yield either native economic or global environmental advantages. There is usually a failure to bargain with all engaged stakeholders and to acknowledge and resolve trade-offs. Subsidies usually have had perverse impacts, and market forces may also become better drivers of economic objectives of recovery programs. Security of tenure and usage rights is a remarkable yet usually disregarded demand for achieving tenability. Identically, several peasants became aware of that so, in order that the MTS become tenable, after the end of the harvest of agricultural crops, there ought to be a flow of advantages, so the bulk payment could be reduced at the time of harvesting of matured trees. The pre-harvest timber profit would be acted as a stimulant to lure and encourage peasants to take position labor on a constant basis. In addition, there is a need for enough education and clearness on how and when the advantages from the timber would be shared because as noted during this study whereas the young peasants primarily cared about the agreement to be signed and 
lawfully binding, the older peasants cared about whether or not their efforts would be secured for their next of kin (Ledger 2009).

\section{REFERENCE}

Acheampong E, Insaidoo TFG, Ros-Tonen MAF. 2016. Management o Ghana's modified taungya system: challenges and strategies for improvement. Agrofor Syst 90 (4): 659-674. DOI: 10.1007/s10457016-9946-7.

Agyeman VK, Kasanga KR, Danso E, Marfo KA, Whiteman A, Asare AB, Yeboah OM, Agyeman F. 2003. Equitable revenue sharing from costs and benefits on) plantation development: A case study of public, private and local community partnerships in Ghana. Draft Report of the Community Forest Plantation Management Programme. Forest Commission, Accra.

Amissah JK. 2009. Utilising a Taungya Plantations Programme to Reduce the Poverty of Farmers in Ashanti Region: A case study of Asuboi and Kunsu Dotiem Farming Communities. Department of Sociology, University of Cape Coast. Ghana.

Anane M. 2003. Implementing Agenda 21: Religion and Conservation in Ghana. United Nations Non-Governmental Liason Service. New York.

Ayivor J. 2007. An Exploration of Policy Implementation in Protected Watershed Areas: Case Study of Digya National Park in the Volta Lake Margins in Ghana. [Thesis]. Ohio University, USA.

Blay D, Appiah M, Damnyag L, Dwomoh FK, Luukkanen O, Pappinen A. 2006. Involving local farmers in rehabilitation of downgraded tropical forests: Some lessons from Ghana. Forestry Commission. Accra Ghana. DOI: 10.1007/s10668-006-9077-9.

Boakye E, Odai SN, Adjei KA, Annor FO. 2008. Landsat Images for Assessment of the Impact of Land-use and Land Cover Changes on the Barekese Catchment in Ghana. Eur J Sci Res 22(2): 269-278.

Brower JE, Zar JH. 1984. Field and Laboratory Methods for General Ecology (2nd ed.). Wm. C. Brown Publishers. Dubuque, IA.

Centre for Remote Sensing and Geographic Information Services (CERSGIS). 2012. University of Ghana, Legon, Accra.

CERSGIS. 2013. Geospatial Data Initiatives in Ghana. Centre for Remote Sensing and Geographic Information Services, University of Ghana, Legon, Accra.

Crowley E. 2010. Rural Employment and Decent Work. Building Employment and Decent Work into Sustainable Recovery and Development. International Labour Organization, Turin, USA

FAO. 2001. Global Forest Resources Assessment 2000 - main report. FAO Forestry Paper No.140. FAO, Rome. Italy.

FAO. 2003. A journal of international forestry and forest industries. Forestry Paper No: 212. FAO, Rome. Italy.

FAO. 2006. Global Forest Resources Assessment. Progress Towards Sustainable Forest Management. Food and Agriculture Organization of the United Nations. Rome, Italy.

Forest Management Plan. 2013. Worobong South Forest Conservation, Akim Portion. Begoro District Forest. Begoro, Ghana.

FPDC [Forest Plantation Development Centre]. 2002. National Forest Plantation Development Programme. Forest Plantation Development Centre, Accra, Ghana.

Ghana Forestry Commission. 2001. Protecting Our Forest and Wildlife Resources for the Future: The Service Charter of the New Forestry Commission. Forestry Commission. Accra, Ghana.

Ghana Forestry Commission. 2002. Annual Report, Ghana Forestry Services Department, Accra. Ghana.

Ghana Forestry Commission. 2004. Progress report on the National Fores Plantation Development Programme. Annual report, 2003-2004. Forestry Commission, Accra, Ghana

GPRS [Ghana Poverty Reduction Strategy]. 2005. Annual Report. Ghana Poverty Reduction Strategy, Accra, Ghana.

Hansen CP, Lund JF, Treue T. 2009. Neither Fast, Nor Easy: The Prospect of Reduced Emissions from Deforestation and Degradation (REDD) in Ghana. Intl For Rev 11 (4): 439-455. DOI: 10.1505/ifor.11.4.439.

Holl KD. 2013. Restoring Tropical Forest. Nature Education Knowledge. University of California, Santa Cruz, CA.

ISSER [Institute of Statistical, Social and Economic Research]. 2008. The State of the Ghanaian Economy in 2007. Institute of Statistical, Social and Economic Research (ISSER), University of Ghana, Legon, Accra, Ghana.
IUCN [International Union for the Conservation of Nature]. 1996 Communities and forest management. A report of the IUCN working group on community involvement in forest management with recommendations to the intergovernmental panel on forest. International Union for the Conservation of Nature, Washington DC.

Laurance WF, Bierregaard RO (eds). 1997. Tropical Forest Remnants: Ecology, Management, and Conservation of Fragmented Communities. University of Chicago Press, Chicago, USA.

Ledger J. 2009. Consequences of the introduction of the Modified Taungya System in Ghana's High Forest Zone for the livelihoods of forest-fringe Communities. KNUST. Kumasi. Ghana.

Lund HG. 2006. Definitions of Forest, Deforestation, Afforestation, and Reforestation. Forest Information Services, Gainesville, VA.

Marfo K, Anchirinah V, Wiggins S. 2002. Environmental policies and livelihoods in the forest margins of Southern Ghana. CSIR, Ghana.

Mas JF. 1999. Monitoring Land Cover Changes: A Comparison of Change Detection Techniques. Intl J Rem Sens 20 (1): 139-152. DOI: $10.1080 / 014311699213659$

MLF [Ministry of Lands and Forestry]. 1996. Forestry development master plan 1996-2000. Ministry of Lands and Forestry, Accra, Ghana.

MLGRD [Ministry of Local Government and Rural Development]. 2006. Medium-term development plan, (2005-2006). Offinso district assembly projections. Ministry of Local Government and Rural Development, Accra, Ghana.

Mwavu EN, Witkowski ETF. 2008. Land-Use and Cover Changes (1988 2002) around Budongo Forest Conservation NW Uganda: Implications for Forest and Woodland Sustainability. Land Degrad Dev 19: 606-622.DOI: 10.1002/ldr.869.

New Mexico State University (NMSU). 2013. The Transect Method. New Mexico State Universtiy, Las Cruces, NM.

NFPDP. 2003. Annual Report. 2003. National Forest Plantation Development Programme, Forestry Commission, Accra, Ghana

NFPDP. 2008. Annual Report. 2008. National Forest Plantation Development Programme, Forestry Commission, Accra, Ghana

O Donnell M. 1992. A new Introduction to Sociology. McGraw-Hill Companies, New York.

Opoku K. 2006. Forest Governance in Ghana. An NGO perspective. A Report Produce for FERN (UK) by Forest Watch Ghana, March 2006. Zuidam Uithof, Utrecht, Netherlands.

Philippoff J, Cox E. 2013. Measuring Abundance: Transects and Quadrants from lessons developed by Erin Baumgartner and Chela Zabin. Smithsonian Environmental Research Center, Washington DC., USA.

Powell FC. 1982. Statistical Tables for the Social, Biological and Physical Sciences. Cambridge University Press, London.

PROFOR. 2011. Programs on Forest: Annual Progress Report 2011. Assessment of Forest Landscape. Recovery Opportunities in Ghana. Collaborative Landscape Recovery in Ghana. PROFOR, Accra, Ghana.

Sayer J. 2004. The Recovery of Forest Biodiversity and Ecological Values. Center for International Forestry Research, Bogor, Indonesia.

Seneadza OK. 2010. Deforestation in Ghana: New Challenges and New Strategies. Forestry Commission, Accra, Ghana.

Singh A. 1989. Digital Change Detection Techniques Using Remotely Sensed Data. Intl J Rem Sens 10 (6): 989-1003. DOI: 10.1080/01431168908903939.

Southgate D, Sierra R, Brown L. 1991. The Causes of Tropical Deforestation in Ecuador: A Statistical Analysis. World Dev 19 (9): 1145-1151. DOI: 10.1016/0305-750X(91)90063-N.

Tankpa V. 2010. Assessment of Spatio-Temporal Vegetation Cover Changes and Its Implications in the Atiwa District of Southern Ghana. [Thesis]. University of Ghana, Legon, Accra.

UNEP [United Nations Environmental Programme]. 2000. Global Environmental Outlook 2. Earthscan, London, UK

Webster A. 1990. An Introduction to Sociology of Development. (2nd ed.). Palgrave Macmillan, London. DOI: 10.1007/978-1-349-205844_1.

World Bank. 2001. World Development Indicators. World Bank, Washington D.C., USA.

World Bank. 2005. Getting to Know the World Bank: A Guide for Young People. World Bank, Washington D.C., USA.

World Bank. 2010. Development and Climate Change. World Development Report. World Bank, Washington D.C., USA. 